\title{
The effect of benfothiamin and vitamın D in ischemia / Reperfusion model of rat skeletal muscle
}

\author{
Özlem Keskin'1, Mehmet Sipahi', Vehbi Yavuz Tokgöz' ${ }^{1}$, Selçuk Takır², \\ Gülname Fındık Güvendi ${ }^{1}$
}

1) Giresun University, Department of Obstetri \& Gynecology, Asst. Prof., MD:, Giresun, Turkey.

2) Giresun University, Department of Obstetri \& Gynecology, Assoc. Prof. MD., Giresun, Turkey.

\begin{abstract}
Background: Benfothiamin is a highly potent form of vitamin B1 protecting endothelial function. On the other hand, vitamin $\mathrm{D}$ provides restoration of muscular tissue by inhibition of apoptosis and acceleration of cellular proliferation following muscle injury. We assumed that the administration of these vitamins in ischemia/ reperfusion (I/R) injury, could reduce the damage by alteration of the release of various oxidant and antioxidant mediators leading to cellular damage.

Materials and Methods: We assigned 30 Wistar Albino males rats into 5 groups. In the control group ( $\mathrm{n}=6)$, rats were anaesthetized and total antioxidant capacity (TAS), total oxidant capacity (TOS), malondialdehyde (MDA), superoxide dismutase (SOD) and nitricoxide (NO) level were measured in lower extremity soleus muscle. Benfotiamin and D were given to the groups and the values of these parameters were evaluated in ischemia reperfusion muscle tissue specimens. All tissues were examined histologically.

Results: We detected a significant change in groups 3 and 4 for antioxidant NO level after ischemia and reperfusion. Therefore, we observed that the administration of vitamin D and benfothiamin increased NO levels in muscle especially during reperfusion. The level of other oxidants TOS and MDA and antioxidants TAS and SOD were not significant during $\mathrm{I} / \mathrm{R}$ at given periods. Overall vitamin $\mathrm{D}$ and benfothiamin have acute beneficial effects especially in improving $\mathrm{I} / \mathrm{R}$ injury of lower extremity, even at non-critical periods.
\end{abstract}

Conclusion: Acute term effects of benfothiamin and vitamin D can be useful during where changes due to I/R. The effects can be evaluated during long term $\mathrm{I} / \mathrm{R}$.

Key Words: Benfothiamin, vitamin D, ischemia / reperfusion injury, skeletal muscle, rats 


\section{Introduction}

Lower extremity can be subjected to ischemia due to certain conditions such as injuries, acute peripheral occlusive diseases and surgical intervention with prolonged tourniquet period. Following reperfusion of ischemic extremity by oxygenized blood, reactive oxygen species including free radicals such as hydroxyl ions (OH-), superoxide anion (O2-), oxygen (O2), hydrogen peroxide ( $\mathrm{H} 2 \mathrm{O} 2)$ and nitric oxide $(\mathrm{NO})$ are produced. These products within the circulation, lead to ischemic injury of the extremity. ${ }^{(1,2)}$ However the organism develops an antioxidant defense system in order to prevent cellular damage due to free radicals. This system includes superoxide dismutase (SOD), glutathione peroxidase (GSH-Px) and catalase (CAT) antioxidant enzyme systems, which are "free radical scavengers" of indirect pathway. ${ }^{(3)}$

Superoxide dismutase (SOD) is an antioxidant enzyme catalyzing the transformation of superoxide free radical (O2-) to hydrogen peroxide(H2O2) and molecular oxygen $(\mathrm{O} 2)$. It provides the alteration of reactive $\mathrm{O} 2$ metabolites and eliminate them from the cell.

The most important and harmful triggering effect of free radicals within the cell, is lipid peroxidation. Lipid peroxidationis defined as oxidation of polyunsaturated fatty acids by free radicals. Malondialdehyde (MDA) is one of the end products of lipid peroxidation and leads to polymerization of membrane components and their cross linking. In turn, this may affect the status of cellular surface, enzyme activity and ion transport. ${ }^{(4,5)}$

$\mathrm{I} / \mathrm{R}$ injury leads to endothelial cell activation and dysfunction. Endothelial cells are potential target of superoxide radicals and also production site of superoxide radicals. Endothelium produces NO and endothelin (ET) which are responsible from microvascular hemostasis. NO tends to reverse the vasoconstrictor effect of ET in arterial circulation. The opposite is true in veins. In I/R injury, ET/NO ratio is impaired in favor of ET. Therefore arterial vasoconstriction and venous vasodilatation occurs. ${ }^{(6)}$

Total oxidant capacity TOS and antioxidant capacity TAS measurements show the oxidant and antioxidant status of serum and tissue. ${ }^{(7)}$ Acute lower extremity ischemia is a clinical condition leading to significant morbidity and mortality even following elimination of ischemia. In case of delayed intervention, these risks are increased. In addition they may be seen in spite of extremity reperfusion. A clinical event chain leading to acute renal and respiratory insufficiency and dysfunction of heart, intestines and spleen, is initiated. ${ }^{(8)}$ The initiation and development of these events should be identified in order to determine medical and surgical treatments to prevent this condition.

There are several studies showing the suppressive aspect of benfothiamin on reactive oxygen products. ${ }^{(9,10)}$ In diabetic rats, benfothiamin normalized many oxygen species. ${ }^{(11)}$ In addition, it reduces harmful oxidative effects in mice with streptozocin(STZ) induced diabetes. (12) Benfothiamin is fat-soluble form of thiamine and can easily pass from cellular membrane which is rich in fatty acid.

There are clinical trials and animal experiment models showing that vitamins $A, C, D$ and $E$ prevent $I / R$ injury. Vitamin $\mathrm{D}$ is fat-soluble and is considered to induce endogenous antioxidant pathways and to have neuroprotective properties by reducing inducible nitric oxide synthase. There are especially references on 1,25-dihydroxy vitamin D3. ${ }^{(13)}$

In our study, acute effects of administration of benfothiamin and vitamin $\mathrm{D}$ were investigated in experimental muscle I/R model. In assessment of this effect, levels of oxidant and antioxidant parameters at pre-determined ischemia and reperfusion periods as well as histopathological tissue samples were examined.

\section{Materials - Methods}

In this interventional animal study, 30 male Wistar Albino rats (aged 8-12 weeks and weighing $321 \pm 69$ g) were included in the experiment, which received ethical approval from the laboratory Animal Unit of Giresun University. The animals were obtained from the same unit, and standard temperature $\left(22 \pm 2^{\circ} \mathrm{C}\right)$ and humidity $(50 \pm 5 \%)$ controlled rooms were used for preserving the rats until the start of the experiment. In addition, a standard diet and tap water were provided ad libitum for the rats.Following the intervention, all rats were sacrificed by obtainingintra-cardiac blood. 
During the interventions, the rats were anesthetized with $50 \mathrm{mg} / \mu \mathrm{l}(8.5 \mathrm{cc})$ of ketamine hydrochloride (HCL) (Ketalar ${ }^{\circledR}$, Pfizer, Inc., İstanbul, Turkey) and $23.32 \mathrm{mg} /$ $\mathrm{ml}(1.5 \mathrm{cc})$ of Xylasine (Rompun ${ }^{\circledR}$, Bayer Healthcare AG, Leverkusen, Germany) through an 0.3-0.5 cc intraperitoneal line. Vital parameters during anesthesia were considered observational. Lower extremity was ligated by silk number 0 at proximal level of femoral artery for lower extremity muscle ischemia (Figure 1). Maintenance of cyanosis and coldness of the extremity was monitored during ischemia.

Following procedures were applied to the groups consecutively:

*Control group: Rats were anesthetized and only a biopsy specimen of $1 \mathrm{~cm}$ was obtained from right leg soleus muscle and transferred into Eppendorf tube with $10 \%$ neutral formalin for histopathological examination. Blood samples were taken from each rat and then they were sacrified.

*Group 1: Right lower extremity was ligated from femoral level and ischemia was maintained for 3 hours. Biopsy from soleus muscle was taken by vertical incision of $1 \mathrm{~cm}$ on the extremity. Following ischemia, extremity tourniquet was removed and reperfusion was maintained for 3 hours. Biopsy from soleus muscle was taken following reperfusion. Rats were sacrificed by obtaining 3 milliliters of intra-cardiac blood.

*Group 2: In rats, ischemia was performed at right extremity and concomitantly subcutaneous $332.000 \mathrm{IU} /$

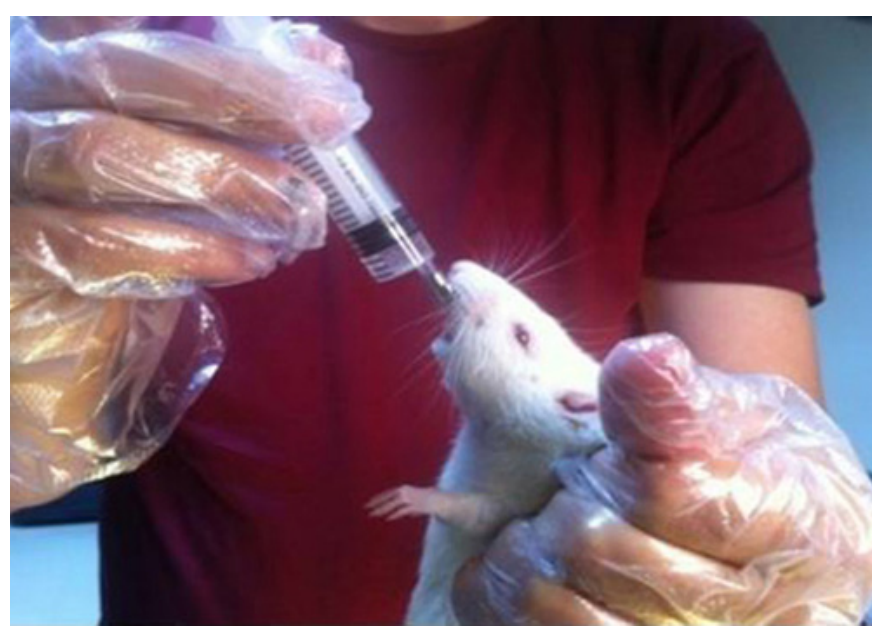

Figure 1 $\mathrm{kg}(8.3 \mathrm{mg} / \mathrm{kg})$ vitamin D (Devit $3 \mathrm{IM} /$ Oral ampoule ${ }^{\circledR}$ $300.000 \mathrm{IU} / \mathrm{ml}$ Deva İlaç) was administered; ischemia was maintained for 3 hours. Biopsy from soleus muscle was taken by vertical incision of $1 \mathrm{~cm}$ on the extremity. Following ischemia, extremity tourniquet was removed and reperfusion was maintained for 3 hours. Biopsy from soleus muscle was taken following reperfusion. Rats were sacrificed by obtaining 3 milliliters of intracardiac blood.

*Group 3: Rats received diluted Benfothiamin (SBenzoyithiaminO-monophosphate B9636-250 MG powder SIGMA-ALDRICH) $70 \mathrm{mg} / \mathrm{kg}$ via oral route by gastric lavage tube (Figure2). Following anesthesia, identical period of $\mathrm{I} / \mathrm{R}$ was administered to rats and biopsy specimens from soleus muscle were taken. Rats were sacrificed by obtaining 3 milliliters of intra-cardiac blood.

*Group 4: Rats received same amount of Benfothiaminvia same way. Following right leg ischemia, subcutaneous vitamin D ampoule was administered. Same period of I/R was done and biopsy specimens were obtained. Rats were sacrificed by obtaining 3 milliliters of intra-cardiac blood.

Tissue samples taken for TAS, TOS, MDA, SOD and $\mathrm{NO}$ were directly transferred into Eppendorf tubes and stored at $-80^{\circ} \mathrm{C}$. Tissue samples taken for histopathological examination were stored in $10 \%$ neutral formalin. SOD, MDA, NO, TAS, TOS determination was as following:

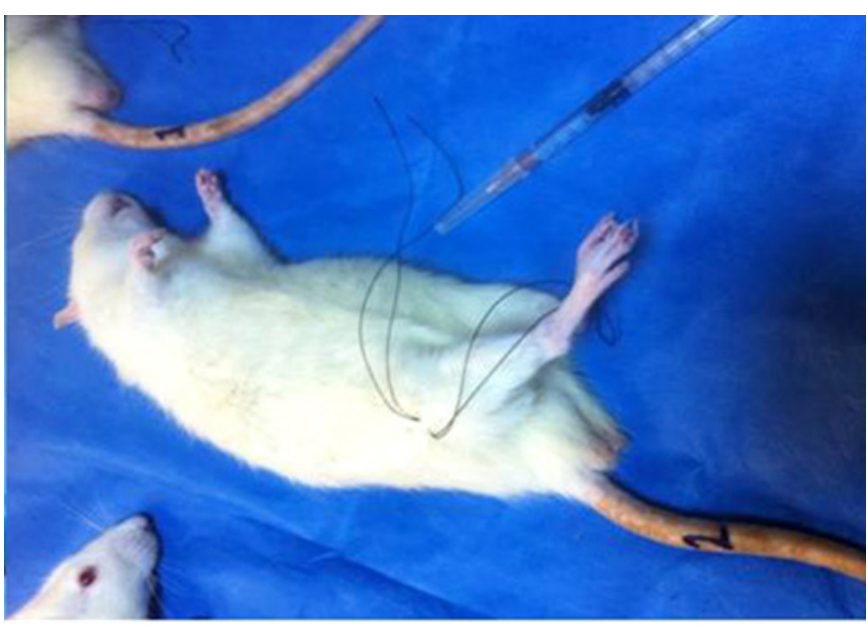

Figure 2 
All tissues were homogenized atRel Assay laboratory. Following homogenization, SOD, MDA and NO tests were done manually according to micro-Elisa method by using Rel Assay Eliza kits on Biotec Elisa device. Other tests were done on Selectra full-automated biochemistry auto-analyzer.

\section{Total Antioxidant Status (TAS)}

TAS levels were measured using commercially available kits (Relassay, Turkey). The novel automated method is based on the bleaching of characteristic color of a more stable ABTS (2,2' - Azino-bis(3-ethylbenzothiazoline-6-sulfonic acid)) radical cation by antioxidants. The assay has excellent precision values, which are lower than $3 \%$. The results were expressed as mmolTrolox equivalent/L. ${ }^{(14)}$

\section{Total Oxidant Status (TOS)}

TOS levels were measured using commercially available kits (Relassay, Turkey. In the new method, oxidants present in the sample oxidized the ferrous iono-dianisidine complex to ferric ion. The oxidation reaction was enhanced by glycerol molecules abundantly present in the reaction medium. The ferric ion produced a colored complex with xylenol orange in an acidic medium. The color intensity, which could be measured spectrophotometrically, was related to the total amount of oxidant molecules present in the sample. The assay was calibrated with hydrogen peroxide and the results were expressed in terms of micromolar hydrogen peroxide equivalent per liter ( $\mu \mathrm{ol} \mathrm{H} 2 \mathrm{O} 2$ equivalent/L). ${ }^{(15)}$ Parameters analyzed for ischemia and reperfusion are shown in Table 1 and Table 2, respectively.

Table 1. TAS, TOS, SOD, MDA and NO concentration for ischemia.

\begin{tabular}{|c|c|c|c|c|c|c|}
\hline Groups & $\begin{array}{c}\text { TAS } \\
(\mathrm{mmol} / \mathrm{tt})\end{array}$ & $\begin{array}{c}\text { TOS } \\
(\mu \mathrm{mol} / \mathrm{lt})\end{array}$ & $\begin{array}{l}\text { SOD } \\
\text { (ng/mlt) }\end{array}$ & $\begin{array}{c}\text { MDA } \\
(\mu \mathrm{mol} / \mathrm{lt})\end{array}$ & $\begin{array}{c}\text { NO } \\
(\mu \mathrm{mol} / / \mathrm{lt})\end{array}$ & $\begin{array}{c}\text { NO } \\
\text { concentration }\end{array}$ \\
\hline Total $n=30$ & mean $\pm S E M$ & mean $\pm S E M$ & mean $\pm S E M$ & mean $\pm S E M$ & mean $\pm S E M$ & mean $\pm S E M$ \\
\hline Control $(n=6)$ & $0.65 \pm 0.05$ & $10.17 \pm 2.80$ & $8.75 \pm 0.66$ & $1.18 \pm 0.15$ & $1.70 \pm 0.40$ & $133.8 \pm 8.9$ \\
\hline G1 $(n=6)$ & $0.65 \pm 0.05$ & $14.66 \pm 3.82$ & $5.5 \pm 0.51$ & $1.05 \pm 0.19$ & $1.42 \pm 0.18$ & $189 \pm 41.3$ \\
\hline G2 $(n=6)$ & $0.38 \pm 0.05$ & $12.03 \pm 0.87$ & $6.11 \pm 0.92$ & $1.008 \pm 0.08$ & $1.33 \pm 0.06$ & $140.5 \pm 6.8$ \\
\hline G3 $(n=6)$ & $0.53 \pm 0.03$ & $11.14 \pm 1.07$ & $5.41 \pm 0.66$ & $622.36 \pm 281$ & $10327.9 \pm 2171.8^{*}$ & $125.3 \pm 8.8$ \\
\hline G4 $(n=6)$ & $0.48 \pm 0.02$ & $11.46 \pm 1.72$ & $7.95 \pm 1.00$ & $825.6 \pm 266.4$ & $15927.5 \pm 1276.8^{*}$ & $203.3 \pm 34.3$ \\
\hline
\end{tabular}

Table 2. TAS, TOS, SOD, MDA, NO and NO concentration for reperfusion.

\begin{tabular}{|c|c|c|c|c|c|c|}
\hline Groups & $\begin{array}{c}\text { TAS } \\
\text { (mmol/lt) }\end{array}$ & $\begin{array}{c}\text { TOS } \\
(\mu \mathrm{mol} / \mathrm{lt})\end{array}$ & $\begin{array}{c}\text { SOD } \\
\text { (ng/mlt) }\end{array}$ & $\begin{array}{c}\text { MDA } \\
(\mu \mathrm{mol} / \mathrm{tt})\end{array}$ & $\begin{array}{c}\text { NO } \\
(\mu \mathrm{mol} / \mathrm{lt})\end{array}$ & $\begin{array}{c}\text { NO } \\
\text { concentration }\end{array}$ \\
\hline Total $n=30$ & mean $\pm S E M$ & mean $\pm S E M$ & mean $\pm S E M$ & meantSEM & mean $\pm S E M$ & meantSEM \\
\hline Control $(n=6)$ & $0.65 \pm 0.05$ & $10.17 \pm 2.80$ & $8.75 \pm 0.66$ & $1.18 \pm 0.15$ & $1.70 \pm 0.40$ & $133.8 \pm 8.9$ \\
\hline G1 $(n=6)$ & $0.65 \pm 0.05$ & $14.66 \pm 3.82$ & $5.5 \pm 0.51$ & $1.05 \pm 0.19$ & $1.42 \pm 0.18$ & $189 \pm 41.3$ \\
\hline $\mathbf{G} 2(n=6)$ & $0.38 \pm 0.05$ & $12.03 \pm 0.87$ & $6.11 \pm 0.92$ & $1.008 \pm 0.08$ & $1.33 \pm 0.06$ & $140.5 \pm 6.8$ \\
\hline G3 $(n=6)$ & $0.53 \pm 0.03$ & $11.14 \pm 1.07$ & $5.41 \pm 0.66$ & $622.36 \pm 281$ & $10327.9 \pm 2171.8^{*}$ & $125.3 \pm 8.8$ \\
\hline G4 $(n=6)$ & $0.48 \pm 0.02$ & $11.46 \pm 1.72$ & $7.95 \pm 1.00$ & $825.6 \pm 266.4$ & $15927.5 \pm 1276.8^{*}$ & $203.3 \pm 34.3$ \\
\hline
\end{tabular}


According to the results of histopathological examination of tissue samples:

Muscle tissue samples taken during ischemia and reperfusion for histopathological examination were stained by hematoxylin-eosin (HE). In each group, the samples were examined for hyalinization, necrosis, inflammation and hemorrhage. Significant histopathological properties of groups were shown in (Figure3). Severity score of histopathological examination was rated as 0: none, 1: mild, 2: moderate, and 3: severe. Mean values of groups were shown in Table 3. It was seen in Figure 3: G1: Focal congestion area in the control group, G2: The hyalinisation in muscle tissue. It was seen in figure 4: G4: Active chronic inflammation at the periphery of bleeding areas involved by neutrophils.

\section{Statistics}

All numeric data were presented as mean \pm standard error of mean(SEM). Two-ways ANOVA multi comparison test was used to compare the parameters between groups. The value $\mathrm{P}<0.05$ was considered as statistically significant.

\section{Results}

All experimental subjects completed the study without mortality. In all groups, TAS, TOS, SOD, MDA, $\mathrm{NO}$ and NO concentration was statistically non-significant in control group and I/R group of 3 hours $(\mathrm{p}>0.05)$. TAS, TOS, SOD, MDA, NO and NO levels of ischemic soleus muscle are shown in Table 1.

There was no statistically significant difference between groups in respect of TAS, TOS, SOD, MDA and NO concentrations for both ischemia and reperfusion at predetermined period. However there was a difference for $\mathrm{NO}$ values.
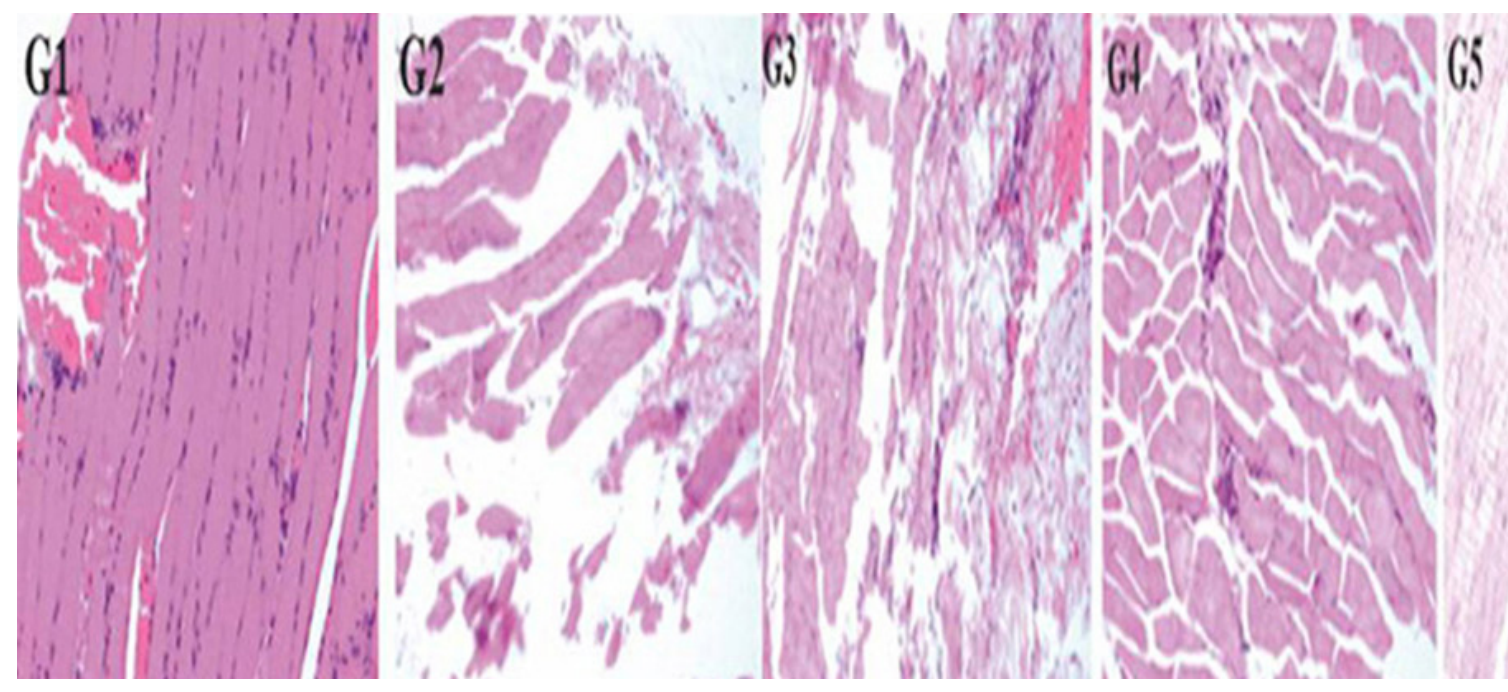

Figure 3

Table 3. Histopathological examination score of muscle.

\begin{tabular}{|c|c|c|c|c|}
\hline Groups & $\begin{array}{c}\text { Mean } \\
\text { Hyalinization }\end{array}$ & $\begin{array}{c}\text { Mean } \\
\text { Necrosis }\end{array}$ & $\begin{array}{c}\text { Mean } \\
\text { Inflammation }\end{array}$ & $\begin{array}{c}\text { Mean } \\
\text { Hemorrhage }\end{array}$ \\
\hline Control & 1 & 0 & 0 & 0.83 \\
\hline G1 & 1.33 & 0 & 0.33 & 1.5 \\
\hline G2 & 1 & 0 & 0.16 & 1.16 \\
\hline G3 & 1.33 & 0 & 0.5 & 1.33 \\
\hline G4 & 1 & 0 & 1.16 & 1.33 \\
\hline
\end{tabular}


NO value was significant in group receiving benfothiamin + vitamin D compared to control group during both ischemia and reperfusion. In group receiving only vitamin $\mathrm{D}$, the significance was present only for reperfusion. This showed us benfothiamin considerably increased the acute protective amount of NO during given $\mathrm{I} / \mathrm{R}$ period and that vitamin $\mathrm{D}$ increased remarkably the NO during reperfusion. Concomitant administrations of benfothiamin and vitamin D led also acute increase in NO. Muscle necrosis was not present in any of groups during I/R periods. Hyalinization, inflammation and hemorrhage were mildly present.

\section{Discussion}

Acute lower extremity I/R may lead to severe tissue damage and systemic complications. Rate of mortality and amputation due to this condition were reported as $15-52 \%$ and $12-22 \%$, respectively. ${ }^{(16)}$ Early diagnosis and early revascularization should be provided as soon as possible. During reperfusion, toxic free oxygen radicals are formed due to re-exposure of tissue to oxygen. (17) In addition to clearance systems developed by the organism to eliminate them, certain substances were also shown to be effective in preventing experimental IR injury. Studies showed that benfothiamin, one of these substances, has suppressive effect on reactive oxygen species. ${ }^{(18)}$ In diabetic rats, benfotihamin normalized many oxygen species. ${ }^{(19)}$ In addition, it reduced harmful oxidative effects in streptozocin (STZ)- induced diabetic rats. ${ }^{(2)}$ There are several studies showing that Benfothiaminsupplement relieved neuropathic pain, vasodilator effect, demonstrated favorable effects on renal and cardiac systems and contributed to wound healing. ${ }^{(21-24)}$

Although there is evidence for effects of vitamin D on aspects of myogenesis, muscle cell signaling, muscle function, and muscle force ${ }^{(25,26)}$ the mechanistic action of vitamin $\mathrm{D}$ on the injured muscle remains largely unknown. We planned this study by considering that benfotihaminand vitamin $\mathrm{D}$ could show protective effects on tissue in IR injury.

Thiamine is not a fat-soluble vitamin. Therefore its oral bioavailability is low. Excess amount of thiamine is eliminated via urine. ${ }^{(27)}$ Benfothiamin is a fat-soluble form of thiaminan can easily penetrates cellular membrane rich in fatty acids. According to a study comparing Benfothiamin and Thiamin, overall bioavailability is $420 \%$ higher $(420 \%$ more recovery in cellular plasma). ${ }^{(28)}$ By considering these properties, acute effects were evaluated during I/R following oral administration in rats. Each rats received benfothiamin $70 \mathrm{mg} / \mathrm{kg}$ by gavage tube and thus individual different dose administration has been prevented.

Biological maximal stimulating dose of vitamin D is $8.3 \mathrm{mg} / \mathrm{kg}(332.000 \mathrm{IU} / \mathrm{kg})$ and this was subcutaneously administered.

Measurements of tissue oxidants and antioxidants were used to determine the damage caused byI/R in the tissue as well as the improving effect of benfothiamin and vitamin $\mathrm{D}$. Total and individual parameters were analyzed during given $\mathrm{I} / \mathrm{R}$ periods.

Histological changes were examined in soleus muscle specimens from experimental animals.

During I/R period of 3 hours, the oxidants TOS and MDA an the antioxidants TAS and SOD were not significantly affected by $\mathrm{I} / \mathrm{R}$ statistically and their concentrations were not significantly changed by administration of both benfothiaminand vitamin D statistically. $\mathrm{NO}$ was not changed during given periods of $\mathrm{I} / \mathrm{R}$. However it was significantly increased by administration of benfothiaminand vitamin $\mathrm{D}$.

In contrast to vasoconstrictor effect in the muscle due to ischemia, This increase in NO level is protective. The beneficial effect of vitamin $\mathrm{D}$ was more significant during reperfusion, while benfothiaminwas significantly effective during both ischemia and reperfusion upon its administration alone as well as in combination with vitamin D. The effect of benfothiaminand benfothiamin+ vitamin D may be clinically beneficial in order to induce protective effect against $\mathrm{NO}$ in any type of traumatic and degenerative vascular $\mathrm{I} / \mathrm{R}$ conditions.

Acute and long term effects of benfothiamin and vitamin $\mathrm{D}$ can be investigated during more prolonged periods where irreversible changes due to I/R occurs. 


\section{References}

1. Cheeseman KH. Mechanisms and effects of lipid per-oxidation. Mol Aspects Med 1993;14:191-7.

2. Clanton TL, Zuo L, Klawitter P. Oxidants and skeletal muscle function: physiologic and pathophysiologic implications. Proc Soc Exp Biol Med 1999;222:253-62

3. Matés JM. Effects of antioxidant enzymes in the molecular control of reactive oxygen species toxicology. Toxicology 2000;153:83104.

4. Girotti AW. Lipid hydroperoxide generation, turnover, and effector action in biological systems. J Lipid Res. 2000; 39:1529-1542.

5. Ertan T, Soran A, Kılıç M, Aşlar AK, Koç M, Cengiz Ö. Kan Malondialdehid ve total antioksidan seviyesinin (TAS) önemi. Cerrahi Tıp Bülteni 2001,2;4: 154-167.

6. García-Villalón AL, Amezquita YM, Monge L, Fernández N, Salcedo A, Diéguez G. Endothelin-1 potentiation of coronary artery contraction after ischemia-reperfusion. Vascul Pharmacol. 2008; 48:109-114.

7. Silva-Adaya D, Pérez-De La Cruz V, Herrera-Mundo MN, Mendoza-Macedo K, Villeda-Hernández J, Binienda Z, Ali SF, Santamaría A. Excitotoxic damage, disrupted energy metabolism, and oxidative stress in the rat brain: antioxidant and neuroprotective effects of Lcarnitine. Neurochem. 2008 May;105(3):677-89.

8. Iyem H, Eren MN. Should embolectomy be performed in late acute lower extremity arterial occlusions? Health Risk Manag. 2009;5:621-6

9. Bakker SJ, Heine RJ, Gans Ro Thiamine may indirectly act as an antioxidant. Diabetologia 1997; 40: 741-2.

10. Gadau S, Emanueli C, Linthout SV, Grainai G, Todaro M, Meloni M. et al. Benfothiamine accelerate the healing of ischaemic diabetic limbs in mice through protein kinase B/Aktmediated potentiation of angiogenesis and inhibition of apoptosis. Diabetologia 2006; 49: 405-20.

11. Beltramo E, Berrone E, Buutiglieri S, Porta M. Thiamine and benfotiamine prevent increased apoptosis in endothelial cells and pericytes cultered in high glucose. Diabetes Metab Res Rev 2004; 20: 330-6.

12. Hammes HP, Du X, Edelstein D, Taguchi T, Matsuma T, Ju Q, et al. Benfotiamine blocks three major pathways of hyperglycemic dam- age and prevents experimental diabetic retinopathy. Nat Med 2003; 9: 294-9.

13. Pin-Keng Shih, Yi-Ching Chen, Ya-Chun Huang, and Chih-Mei Cheng. Pretreatment of Vitamin D3 Ameliorates Lung and Muscle Injury Induced by Reperfusion of Bilateral Femoral Vessels in a Rat Model Journal of Surgical Research 2011 Nov;171: 323-328 .

14. Erel O. A novel automated direct measurement method for total antioxidant capacity using a new generation, more stable ABTS radicalcation. Clin Biochem 2004;37:277-85.

15. Erel O. A new automated colorimetric method for measuringtotal oxidant status. Clin Biochem 2005;38:1103-11.

16. Homer-Vanniasinkam S, Rowlands TE, Hardy SC, Gough MJ. Skeletal muscle ischaemia-reperfusion injury: further characterisation of a rodent model. Eur J Vasc Endovasc Surg 2001 Dec;22(6):523-7.

17. Wu L, Yang T, Yang C, Yao N, Wang H, Fang J, Xu Y. Delayed neurological deterioration after surgery for intraspinal meningiomas: Ischemia-reperfusion injury in a rat model. Oncol Lett. 2015 Oct;10(4):2087-2094.

18. Gadau S, Emanueli C, Linthout SV, Grainai G, Todaro M, Meloni M. et al. Benfothiamine accelerate the healing of ischaemic diabetic limbs in mice through protein kinase B/Aktmediated potentiation of angiogenesis and inhibition of apoptosis. Diabetologia 2006; 49: 405-20.

19. Beltramo E, Berrone E, Buutiglieri S, Porta M. Thiamine and benfotiamine prevent increased apoptosis in endothelial cells and pericytes cultered in high glucose. Diabetes Metab Res Rev 2004; 20 : $330-6$.

20. Hammes HP, Du X, Edelstein D, Taguchi T, Matsuma T, Ju Q, et al. Benfotiamine blocks three major pathways of hyperglycemic damage and prevents experimental diabetic retinopathy. Nat Med 2003; 9: 294-9.

21. Winkler G, Pal B, Nagybegany E, Ory I, Farkli benfotiamin doz uygulamalarinin agrili diyabetik nöropati tedavisine üzerine etkisi. Arzneimettelforschung. 1999 Mar;49(3):220-4.

22. Gadau S, Emanueli C, van LS, et al. Benfotiamin, protein kinaz B/ Akt anjiyogenez potansiyelizasyonu ve apoptoz önlenmesi yoluyla farelerdeki iskemik diyabetik uzuvlarin iyilesmesini hizlandirir Diabetologia. 2006 Feb;49(2):405-20. 
23. Babaei-Jadidi R, Karachalias N, Ahmed N, Battah S, Thornalley PJ.Yeni baslayan diyabetik nöropatinin yüksek doz tiamin ve benfotiamin ile önlenmesi. Diabetes. 2003 Aug;52(8):2110-20.

24. Ceylan-Isik AF, Wu S, Li Q, Li SY, Ren J. High-dose benfotiamine rescues cardiomyocyte contractile dysfunction in streptozotocininduced diabetes mellitus. J Appl Physiol. 2006 Jan;100(1):150-6.

25. Ceglia L: Vitamin D and its role in skeletal muscle. Curr Opin Clin Nutr Metab Care 2009 Nov; 12(6):628-33.

26. Hamilton B: Vitamin D and human skeletal muscle. Scand J Med Sci Sports 2010; 20:182-190
27. Geyer J, Netzel M, Bitsch I, Frank T, Bitsch R, Krämer K et al. Bioavailability of water- and lipid-soluble thiamin compounds in broiler chickens. Int J Vitam Nutr Res. 2000 Dec;70(6):311-6.

28. Frank T, Bitsch R, Maiwald J, Stein G High thiamine diphosphate concentrations in erythrocytes can be achieved in dialysis patients by oral administration of benfontiamine. Eur J Clin Pharmacol. 2000 Jun;56(3):251-7.

29. Várbíró S, Sára L, Antal P, Monori-Kiss A, Tőkés AM, Monos E et al. Lower-limb veins are thicker and vascular reactivity is decreased in a rat PCOS model: concomitant vitamin D3 treatment partially prevents these changes. 2014 Sep 15;307(6):H848-57.

Received: $20 / 05 / 2018$

Accepted: $30 / 05 / 2018$

Published: 05/06/2018

Disclosure and conflicts of interest:

The authors declare no conflict of interest.

Corresponding author:

Özlem Keskin

Mail: zlemkeskin@hotmail.com 